\title{
The prognostic role of serum C-X-C chemokine receptor type 4 in patients with metastatic or recurrent colorectal cancer
}

This article was published in the following Dove Press journal:

OncoTargets and Therapy

I June 2016

Number of times this article has been viewed

\author{
Yoon Ji Choi' \\ Won Jin Chang' \\ Sang Won Shin' \\ Kyong Hwa Park' \\ Seung Tae Kim² \\ Yeul Hong Kim' \\ 'Division of Hematology-Oncology, \\ Department of Internal Medicine, \\ Korea University College of Medicine, \\ ${ }^{2}$ Division of Hematology-Oncology, \\ Department of Medicine, Samsung \\ Medical Center, Sungkyunkwan \\ University School of Medicine, Seoul, \\ South Korea
}

Correspondence: Seung Tae Kim Division of Hematology-Oncology, Department of Medicine, Samsung Medical Center, Sungkyunkwan University School of Medicine, 50 Irwon-dong Gangnam-gu, Seoul I35-7I0, South Korea Tel +82 234100297

Fax +82 234101754

Email seungtael.kim@samsung.com

Yeul Hong Kim

Division of Hematology-Oncology, Department of Internal Medicine, Korea University Anam Hospital, Korea University College of Medicine, I26-I, Anam-dong 5-ga, Seongbuk-gu, Seoul 136-705, South Korea

Tel +82 29205569

Fax +82 29206622

Email yhk0215@korea.ac.kr
Background: $\mathrm{C}-\mathrm{X}-\mathrm{C}$ chemokine receptor type 4 (CXCR4) is involved in tumor progression including angiogenesis, metastasis, and survival. However, whether serum CXCR4 levels in metastatic or recurrent colorectal cancer have a prognostic role, have not been evaluated.

Methods: We analyzed serum samples from 55 patients with advanced colorectal cancer diagnosed between March 2008 and July 2011. Serum CXCR4 levels were quantified by a commercially available enzyme-linked immunosorbent assay (ELISA) kit.

Results: The median age of the patients was 62 years, and all patients received systemic chemotherapy of two or more lines. The median serum CXCR4 level was $283.47 \mathrm{pg} / \mathrm{mL}$ (range: 77.48-846.52). Patients with two or more metastatic sites, liver metastasis, or higher CA 19-9 level ( $>37 \mathrm{IU} / \mathrm{mL}$ ) showed significantly higher levels of serum CXCR4 than patients without. The median overall survival (OS) of all patients was 19.53 months. OS was significantly longer in patients with lower CXCR4 levels $(\leq 240.45 \mathrm{pg} / \mathrm{mL})$ compared with those having higher CXCR4 levels ( $>240.45 \mathrm{pg} / \mathrm{mL}$ ) (median OS: 26.50 vs 17.03 months, $P=0.046$ ). Univariate analysis showed that liver metastasis, no palliative surgery, and higher levels of CXCR4 $(>240.45 \mathrm{pg} / \mathrm{mL})$ had a significantly poor prognostic value with regard to OS $(P<0.05)$.

Conclusion: Serum CXCR4 level was positively correlated with metastatic sites, liver metastasis, or higher CA 19-9 level. Also, there was a significant difference in OS according to the level of CXCR4 expression. These findings suggest that serum CXCR4 levels may be a useful surrogate marker of clinical outcome in metastatic or recurrent colorectal cancer.

Keywords: CXCR4, colorectal cancer, overall survival, prognosis

\section{Introduction}

Colorectal cancer $(\mathrm{CRC})$ remains the third most commonly diagnosed cancer in males and the second in females, with an estimated 1.4 million cases and 693,900 deaths occurring worldwide in 2012. ${ }^{1}$ Although the 5-year survival rate for patients with localized CRC approaches $90 \%$, the rate for patients with distant metastatic CRC is $13 \% .^{2}$ In most cases, the mortality is caused by liver metastasis.

Recently, the role of chemokines in cancer metastasis has been highlighted. Target organs produce and release specific chemokines that attract distant cancer cells carrying specific chemokine receptors. ${ }^{3,4}$ The C-X-C chemokine receptor type 4 (CXCR4) and its chemokine ligand 12 (CXCL12) are two key factors in the cross talk between cancer cells and their microenvironment, which makes them promising targets for cancer therapy. ${ }^{5}$

CXCR4 overexpression is known to occur in $>20$ human tumor types, including ovarian, ${ }^{6}$ prostate, ${ }^{7}$ esophageal, ${ }^{8}$ melanoma, ${ }^{9}$ and renal cell carcinoma. ${ }^{10}$ CXCR4 
expression is also shown to promote angiogenesis, which has been shown to be critical for cancer cell survival in previous studies. ${ }^{11,12}$ Furthermore, preclinical studies using several types of cancer models demonstrated that directed metastasis of cancer cells is mediated by CXCR4 activation and migration of cancer cells toward CXCL12-expressing organs, including bone marrow, liver, lungs, and lymph nodes. $^{13-15}$

Several retrospective studies have demonstrated that high CXCR4 expression in cancer specimens is associated with a poor prognosis in several human tumor types. ${ }^{16-18}$ Specifically, CXCR4 expression in primary CRC had significant association with recurrence, survival, and liver metastasis in a retrospective study in CRC patients. ${ }^{17}$ Most of the studies demonstrating the role of CXCR4 expression as a prognostic factor inspected tumor tissue and CXCR4 levels. However, whether serum CXCR4 levels in metastatic or recurrent CRC have a prognostic role have not been evaluated. Here, we examine serum specimens from patients with CRC to resolve whether serum CXCR4 levels can be a significant prognostic factor for patients with metastatic or recurrent CRC.

\section{Materials and methods Study population}

From March 2008 to July 2011, blood samples from 65 patients with newly diagnosed metastatic or recurrent CRC were collected, and we reviewed the data of these patients thereafter. We analyzed serum samples from 55 patients after excluding patients with a decreased sample volume or who had already started treatment before the blood samples were obtained. All the samples used in analysis were collected before starting a novel treatment. After collection, the samples were kept at room temperature for 2 hours to allow clotting and then were immediately centrifuged $(1,000 \times g)$ for 15 minutes at $4^{\circ} \mathrm{C}$ and were then cryopreserved at $-80^{\circ} \mathrm{C}$.

The study was approved by the Korea University Anam Hospital Institutional Review Board, and written informed consent was obtained from each participant.

\section{Analysis of CXCR4 plasma levels}

The level of plasma CXCR4 was quantified using a commercially available ELISA kit (soluble Human CXC-chemokine Receptor 4 ELISA Kit; Cusabio Biotech Co. Ltd., Wuhan, People's Republic of China). The detailed procedure of this 4.5-hour solid-phase ELISA was as follows. One hundred microliters of standard and sample were added to each well and incubated for 2 hours at $37^{\circ} \mathrm{C}$. This step was followed by the addition of $100 \mu \mathrm{L}$ of biotin antibody to each well and incubation for 1 hour at $37^{\circ} \mathrm{C}$, and then each well was aspirated and washed three times. Horseradish peroxidaseavidin $(100 \mu \mathrm{L})$ conjugate was added to each well, and the plates were incubated for 1 hour at $37^{\circ} \mathrm{C}$, and subsequently the aspiration/wash process was performed five times. Tetramethylbenzidine (TMB) substrate $(90 \mu \mathrm{L})$ was added to each well, and the plates were incubated for 30 minutes at $37^{\circ} \mathrm{C}$ and protected from light. Stop solution $(50 \mu \mathrm{L})$ was then added to each well. The optical density of each well was determined using a niMARK ${ }^{\mathrm{TM}}$ microplate reader (Bio-Rad Laboratories Inc., Hercules, CA, USA) at $450 \mathrm{~nm}$ and wavelength correction was performed at $540 \mathrm{~nm}$. All the serum samples were measured three times, and the mean level of the measurements was used for analysis.

\section{Statistical analysis}

Statistical analyses were carried out using IBM SPSS Statistics Version 20.0 (IBM Corporation, Armonk, NY, USA). Normality of distribution was tested using the ShapiroWilks' $W$-test, and statistical significances of differences were tested using independent $t$-tests. If the groups were not normally distributed, the Mann-Whitney $U$-test was applied. Since there was no reference range available for serum CXCR4 levels, we chose the level by using receiver operating characteristic (ROC) curves for predicting 2-year survival rate. Survival analyses were performed using Kaplan-Meier survival analysis and the Cox's proportional hazards model. Univariate analysis was performed to identify several prognostic factors of CRC patients by Kaplan-Meier survival analysis, and the $P$-value was calculated by the logrank test. Multivariate analysis of meaningful parameters was performed with the Cox regression model. The results were considered statistically significant if $P<0.05$.

\section{Results}

\section{Patient characteristics}

A total of 55 advanced CRC patients were analyzed. Baseline characteristics are presented in Table 1. Of note, patients were predominantly male $(63.6 \%)$ with the median age of 62 years (range: $39-82$ ), and $85.5 \%$ of the patients had metastatic disease. More than half of the patients had undergone palliative surgery, and liver metastases were observed in $67.3 \%$ of the patients. Forty-five percent of patients had mutant KRAS and all patients received two or more lines of chemotherapy. The median serum CXCR4 level of all enrolled patients was $271.76 \mathrm{pg} / \mathrm{mL}$ (range: 56.52-860.10). 
Table I Patients' clinical and disease characteristics

\begin{tabular}{|c|c|c|}
\hline Variables & $\begin{array}{l}\text { No of patients } \\
(\mathrm{N}=55)\end{array}$ & $\begin{array}{l}\% \text { of } \\
\text { patients }\end{array}$ \\
\hline \multicolumn{3}{|l|}{ (years) } \\
\hline$\leq 65$ & 40 & 72.7 \\
\hline$>65$ & 15 & 27.3 \\
\hline \multicolumn{3}{|l|}{ Sex } \\
\hline Male & 35 & 63.6 \\
\hline Female & 20 & 36.4 \\
\hline \multicolumn{3}{|l|}{ Disease status } \\
\hline Metastatic & 47 & 85.5 \\
\hline Recurrent & 8 & 14.5 \\
\hline \multicolumn{3}{|l|}{ Palliative surgery } \\
\hline Yes & 36 & 65.5 \\
\hline No & 19 & 34.5 \\
\hline \multicolumn{3}{|l|}{ Primary site } \\
\hline Colon & 39 & 70.9 \\
\hline Rectum & 16 & 29.1 \\
\hline \multicolumn{3}{|l|}{ No of metastatic sites } \\
\hline $0-1$ & 13 & 23.6 \\
\hline$\geq 2$ & 42 & 76.4 \\
\hline \multicolumn{3}{|l|}{ Liver metastasis } \\
\hline Yes & 37 & 67.3 \\
\hline No & 18 & 32.7 \\
\hline \multicolumn{3}{|l|}{ KRAS } \\
\hline Mutant & 25 & 45.5 \\
\hline Wild type & 30 & 54.5 \\
\hline \multicolumn{3}{|l|}{ CA $19-9$} \\
\hline$\leq 37 \mathrm{IU} / \mathrm{mL}$ & 36 & 65.5 \\
\hline$>37 \mathrm{IU} / \mathrm{mL}$ & 19 & 34.5 \\
\hline \multicolumn{3}{|l|}{ Chemotherapy } \\
\hline First line & 55 & 100.0 \\
\hline Second line & 55 & 100.0 \\
\hline Third or more line & 39 & 70.9 \\
\hline $\begin{array}{l}\text { CXCR4 level, median } \\
\text { (range) }(\mathrm{pg} / \mathrm{mL})\end{array}$ & $271.76(56.52-860.10)$ & \\
\hline
\end{tabular}

Abbreviation: CXCR4, C-X-C chemokine receptor type 4.

\section{Serum CXCR4 level according to clinical features}

Age, sex, disease status (metastatic or recurrent), surgery, location, and tissue KRAS mutation status did not influence the serum CXCR4 levels (Table 2).

The median serum CXCR4 level from patients with two or more metastatic sites was $315.10 \mathrm{pg} / \mathrm{mL}$, while that from patients with one or no metastatic site was $224.86 \mathrm{pg} / \mathrm{mL}$. The difference was statistically significant $(P=0.011)$. The median serum CXCR4 level from patients with liver metastasis was significantly higher than that from patients with no liver metastasis (321.76 and $222.24 \mathrm{pg} / \mathrm{mL}$, respectively; $P=0.033$ ). Additionally, there was a meaningful difference with regard to the influence of CA 19-9 levels on serum
Table 2 Comparison of the median serum CXCR4 levels according to clinical features

\begin{tabular}{|c|c|c|c|}
\hline Variables & $\begin{array}{l}\text { No of patients } \\
(\mathrm{N}=55)\end{array}$ & $\begin{array}{l}\text { Median CXCR4 } \\
\text { level (pg/mL) }\end{array}$ & $P$-value \\
\hline $\begin{array}{l}\text { Age, median } \\
\text { (range) (years) }\end{array}$ & $62(39-82)$ & & \\
\hline$\leq 65$ & 40 & 277.36 & 0.424 \\
\hline$>65$ & 15 & 271.05 & \\
\hline \multicolumn{4}{|l|}{ Sex } \\
\hline Male & 35 & 246.29 & 0.351 \\
\hline Female & 20 & 326.40 & \\
\hline \multicolumn{4}{|l|}{ Disease status } \\
\hline Metastatic & 47 & 271.76 & 0.467 \\
\hline Recurrent & 8 & 273.67 & \\
\hline \multicolumn{4}{|c|}{ Palliative surgery } \\
\hline Yes & 36 & 250.33 & 0.502 \\
\hline No & 19 & 301.05 & \\
\hline \multicolumn{4}{|l|}{ Primary site } \\
\hline Colon & 39 & 310.74 & 0.646 \\
\hline Rectum & 16 & 287.55 & \\
\hline \multicolumn{4}{|c|}{ No of metastatic sites } \\
\hline $0-1$ & 13 & 224.86 & 0.011 \\
\hline$\geq 2$ & 42 & 315.10 & \\
\hline \multicolumn{4}{|l|}{ Liver metastasis } \\
\hline Yes & 37 & 321.76 & 0.033 \\
\hline No & 18 & 222.24 & \\
\hline \multicolumn{4}{|l|}{ Tissue KRAS } \\
\hline Mutant & 25 & 248.43 & 0.589 \\
\hline Wild type & 30 & 292.0 & \\
\hline \multicolumn{4}{|l|}{ CA 19-9 } \\
\hline$\leq 37 \mathrm{IU} / \mathrm{mL}$ & 36 & 240.45 & 0.037 \\
\hline$>37 \mathrm{IU} / \mathrm{mL}$ & 19 & 351.76 & \\
\hline
\end{tabular}

Abbreviation: CXCR4, C-X-C chemokine receptor type 4.

CXCR4 levels. The median serum CXCR4 level from patients with abnormally high CA 19-9 levels ( $>37 \mathrm{IU} / \mathrm{mL})$ was $351.76 \mathrm{pg} / \mathrm{mL}$, while that from patients with normal CA 19-9 levels $(\leq 37 \mathrm{IU} / \mathrm{mL})$ was $240.45 \mathrm{pg} / \mathrm{mL}(P=0.037$; Table 2).

\section{Survival}

The median follow-up time for all patients, estimated by the reverse Kaplan-Meier method, was 44.67 months. The median overall survival (OS) of all CRC patients was 19.53 months (95\% confidence interval [CI]: 15.90-23.16) (Figure 1). The results of univariate analysis are shown in Table 3. Sex, age, disease status, location of primary site, number of metastatic sites, CA 19-9 level, and tissue KRAS mutation status failed to show any relation to survival. However, liver metastasis was an excellent predictor of outcome. The median OS of patients with liver metastasis was 18.37 months (95\% CI: 14.88-21.86), while that 


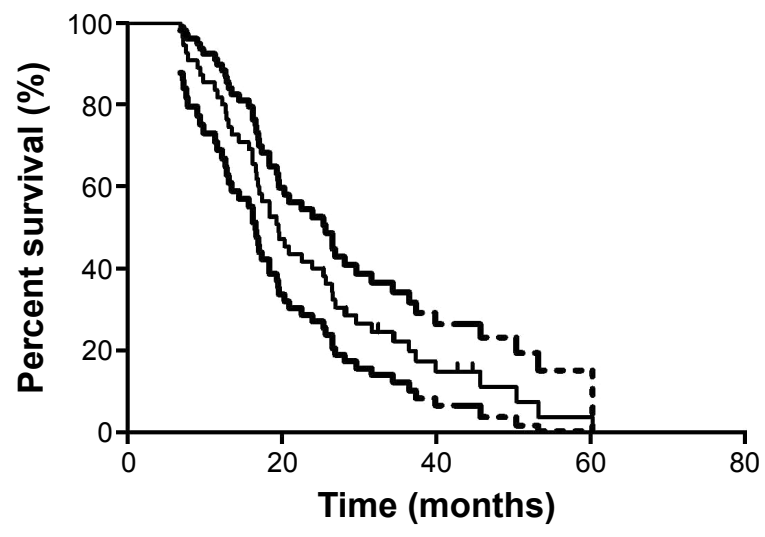

Figure I Kaplan-Meier curves of overall survival in all patients $(\mathrm{N}=55)$.

Note: Dashed lines are upper bound and lower bound, respectively, of $95 \% \mathrm{Cl}$ of Kaplan-Meier estimates.

Abbreviations: $\mathrm{Cl}$, confidence interval; OS, overall survival.

of patients without liver metastasis was 29.63 months $(P=0.033)$. Additionally, patients who had undergone palliative surgery had a better prognosis than patients who had not undergone palliative surgery (23.93 and 16.20 months, respectively; $P=0.036$ ).

Table 3 Prognostic factors for OS in univariate analysis $(\mathrm{N}=55)$

\begin{tabular}{|c|c|c|c|}
\hline Variables & $\begin{array}{l}\text { Median OS } \\
\text { (months) }\end{array}$ & $95 \% \mathrm{Cl}$ & $P$-value \\
\hline \multicolumn{4}{|l|}{ Sex } \\
\hline Male & 17.03 & $|2.7|-2 \mid .353$ & 0.529 \\
\hline Female & 19.53 & $9.45-29.61$ & \\
\hline \multicolumn{4}{|l|}{ Age (years) } \\
\hline$\leq 65$ & 18.37 & $|4.8|-2 \mid .93$ & 0.365 \\
\hline$>65$ & 23.93 & $13.24-34.62$ & \\
\hline \multicolumn{4}{|l|}{ Disease status } \\
\hline Metastatic & 20.33 & 15.98-24.68 & 0.728 \\
\hline Recurrent & 17.03 & $15.37-18.69$ & \\
\hline \multicolumn{4}{|l|}{ Primary site } \\
\hline Colon & 20.33 & $16.37-18.10$ & 0.585 \\
\hline Rectum & 16.20 & |4.30-23.23 & \\
\hline \multicolumn{4}{|c|}{ No of metastatic sites } \\
\hline $0-1$ & 18.37 & $2.33-34.4 I$ & 0.322 \\
\hline$\geq 2$ & 19.53 & $|5.05-24.0|$ & \\
\hline \multicolumn{4}{|l|}{ Liver metastasis } \\
\hline Yes & 18.37 & $|4.88-2| .86$ & 0.033 \\
\hline No & 29.63 & $20.58-38.68$ & \\
\hline \multicolumn{4}{|l|}{ Palliative surgery } \\
\hline Yes & 23.93 & $15.93-31.93$ & 0.036 \\
\hline No & 16.20 & | I.79-20.6| & \\
\hline \multicolumn{4}{|l|}{ CA $19-9$} \\
\hline$\leq 37 \mathrm{IU} / \mathrm{mL}$ & 20.90 & $|2.0|-29.79$ & 0.120 \\
\hline$>37 \mathrm{IU} / \mathrm{mL}$ & 17.40 & $9.91-24.89$ & \\
\hline \multicolumn{4}{|l|}{ Tissue KRAS } \\
\hline Mutant & 18.37 & $14.40-22.34$ & 0.281 \\
\hline Wild type & 20.90 & $|1.5|-30.29$ & \\
\hline \multicolumn{4}{|l|}{ CXCR4 } \\
\hline$\leq 240.45 \mathrm{pg} / \mathrm{mL}$ & 26.50 & $17.37-35.63$ & 0.046 \\
\hline$>240.45 \mathrm{pg} / \mathrm{mL}$ & 17.03 & |4.67-19.39 & \\
\hline
\end{tabular}

Abbreviations: $\mathrm{Cl}$, confidence interval; CXCR4, C-X-C chemokine receptor type 4; OS, overall survival.

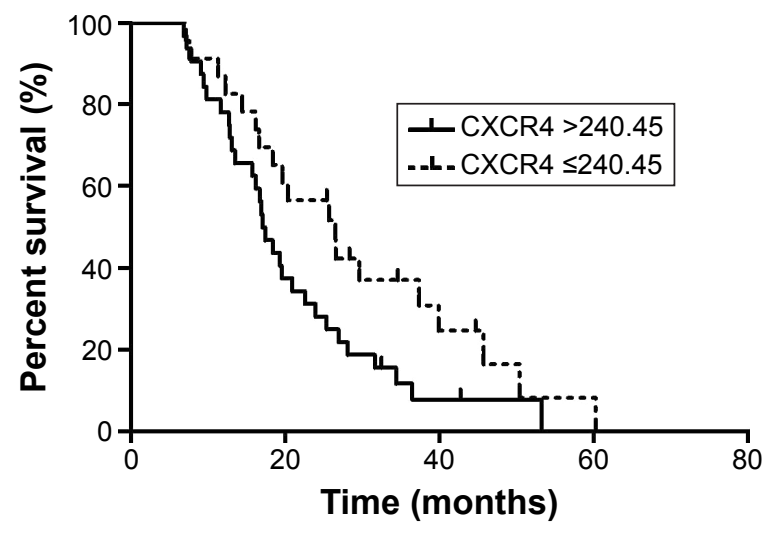

Figure 2 Kaplan-Meier curves of overall survival by serum CXCR4 levels measured in serum samples.

Abbreviation: CXCR4, C-X-C chemokine receptor type 4.

We also sought to identify whether serum CXCR4 levels could predict prognosis. The advanced CRC patients were regrouped according to their serum CXCR4 levels. The best cutoff value of serum CXCR4 level was set up as $240.45 \mathrm{pg} / \mathrm{mL}$ (area under the ROC curve [AUC] 0.65, sensitivity $0.697,1$-specificity 0.591 ) using ROC curves to predict 2-year survival. The median OS of the patients with a relatively higher serum CXCR4 level ( $\geq 240.45 \mathrm{pg} / \mathrm{mL}$ ) was 17.03 months (95\% CI: 14.67-19.39), whereas that of patients with a relatively lower serum CXCR4 level $(<240.45 \mathrm{pg} / \mathrm{mL})$ were 26.50 months (95\% CI: 17.37-35.63). The KaplanMeier survival curve according to serum CXCR4 level is shown in Figure 2, and this difference was statistically significant $(P=0.046)$.

Multivariate analysis of meaningful parameters was performed with the Cox regression model (Table 4). Liver metastasis and palliative surgery showed statistically significant differences. The hazard ratio of the liver metastasis was 2.114 (95\% CI: $1.067-4.191 ; P=0.032)$ and that of the palliative surgery was 0.456 (95\% CI: $0.239-0.870 ; P=0.017$ ). However, serum CXCR4 levels failed to show a statistical significance in the multivariate analysis $(P=0.239)$.

Table 4 Prognostic factors for OS in multivariate analysis $(\mathrm{N}=55)$

\begin{tabular}{llll}
\hline Variables & $\begin{array}{l}\text { Hazard } \\
\text { ratio }\end{array}$ & $\mathbf{9 5 \%} \mathbf{C l}$ & $\begin{array}{l}\text { Multivariate } \\
\text { P-value }\end{array}$ \\
\hline $\begin{array}{l}\text { Liver metastasis } \\
\text { Yes }\end{array}$ & 2.114 & $1.067-4.191$ & 0.032 \\
$\quad$ No & & & \\
$\begin{array}{l}\text { Palliative surgery } \\
\text { Yes }\end{array}$ & 0.456 & $0.239-0.870$ & 0.017 \\
$\quad$ No \\
$\begin{array}{l}\text { CXCR4 } \\
\quad 240.45 \mathrm{pg} / \mathrm{mL}\end{array}$ & $1.45 \mathrm{I}$ & $0.78 \mathrm{I}-2.694$ & 0.239 \\
$>240.45 \mathrm{pg} / \mathrm{mL}$ & & & \\
\hline
\end{tabular}

Abbreviations: $\mathrm{Cl}$, confidence interval; CXCR4, C-X-C chemokine receptor type 4; OS, overall survival. 


\section{Discussion}

CXCR4, originally named LESTR or fusin, is a G-proteincoupled chemokine receptor. ${ }^{19}$ It exerts its biological effect by binding to its ligand CXCL12 (previously termed stromal cell-derived factor 1), ${ }^{20,21}$ activating the downstream protein kinase B (AKT)/mitogen-activated protein kinases (MAPKs) signaling pathway. ${ }^{7}$ Intense in vitro research implicated CXCR4 in numerous cancer-specific metastases including breast, ${ }^{3}$ colon, ${ }^{22}$ lung, ${ }^{23}$ kidney, ${ }^{24}$ melanoma,,${ }^{25,26}$ and prostate cancer. ${ }^{7}$ A growing body of evidence indicated that directed metastasis of cancer cells was mediated by CXCR4 activation toward a concentration gradient of CXCL12. CXCL12 expression levels are high in the liver, lung, and bone marrow, making them common metastasis sites.

Several retrospective studies demonstrated that high CXCR4 expression in cancer specimens is associated with a poor prognosis in several human tumor types. ${ }^{16-18}$ Specifically, one study suggested that high expression of CXCR4 in tumor specimens from early-stage CRC patients was associated with an increased risk of locoregional recurrence and/or liver metastasis, and that high CXCR4 expression in primary tumor specimens from metastatic CRC patients correlated with worse overall median survival. ${ }^{27}$ Most of these studies have been conducted in tissue specimens. Few studies have reported serum CXCR4 levels, although one study counted CXCR4-positive circulating endothelial cells and demonstrated that CXCR4-positive circulating endothelial cell levels may predict the prognosis of bevacizumab combination chemotherapy.$^{28}$ No current study has presented direct serum levels of CXCR4 in CRC.

As the initial report of clinical utility of serum CXCR4 levels, our study may serve as a basis for determining the ranges of low or high serum CXCR4 levels for metastatic CRC patients. In this study, serum CXCR4 levels were positively correlated with more metastatic sites, liver metastasis, and an abnormal level of CA 19-9, implying that serum CXCR4 levels may be associated with tumor burden. These findings suggest that CXCR 4 expression may promote tumor metastases. A previous in vitro study that demonstrated the role of CXCR4 in metastases supports this suggestion..$^{22}$

Another important result of our study was that serum CXCR4 levels were associated with a patient's prognosis. Liver metastases and metastatic burden are a powerful predictor of survival, and serum CXCR4 levels properly reflect liver metastasis and metastatic burden. Thus, we could assume that the serum CXCR4 levels may be a useful prognostic factor. In univariate analysis, serum CXCR4 level was a statistically significant predictor of survival in metastatic CRC patients. In multivariate analysis, however, serum CXCR4 levels lose statistical power, and the only meaningful factors were liver metastasis and no surgery. This may be caused by small sample size or multiple collinearity between liver metastasis and CXCR4 level.

Recent use of antagonist peptides to the CXCR4 receptor has shown promise for future therapeutic strategies that may allow control of tumor spread by blocking the CXCR4 receptor. ${ }^{29,30}$ Additionally, CXCR4 level was shown to be correlated with VEGF level in a previous study investigating osteosarcoma, ${ }^{31}$ and CXCR4-positive circulating endothelial cells were correlated with the prognosis of bevacizumab, a VEGF monoclonal antibody in the CRC patients. ${ }^{28}$ Further evaluation is needed to verify the role of serum CXCR4 level as a predictive marker for CXCR4 antagonists or VEGF inhibitors.

There are some limitations of this study. First, the number of study samples was relatively small. Also, serum CXCR4 levels of healthy control subjects and early-stage CRC patients were not assessable. For this reason, we could not compare serum CXCR4 levels of metastatic CRC patients with healthy subjects and early-stage CRC patients. Thus, the role of CXCR4 in tumorigenesis and progression of localized cancer stage could not be fully investigated. Next, this study could not verify the role of serum CXCR4 as a predictive marker of bevacizumab because we did not examine VEGF levels and the number of patients receiving bevacizumab was only six of the 55 patients.

\section{Conclusion}

The results of this study suggest that serum CXCR4 levels are strongly associated with the number of metastatic sites and liver metastasis in advanced CRC. In addition, serum CXCR4 levels may be a possible prognostic marker in metastatic/recurrent CRC. To clarify the role of serum CXCR4 as a definite prognostic marker and predictive marker for bevacizumab, future studies of molecular mechanisms and the correlation with CXCR4 and VEGF expression in cancer tissues are needed with large samples.

\section{Acknowledgment}

This research was supported by a grant of the Korea Health Technology R\&D Project through the Korea Health Industry Development Institute (KHIDI), funded by the Ministry of Health \& Welfare, Republic of Korea (grant number: HI14C2750).

\section{Disclosure}

The authors report no conflicts of interest in this work. 


\section{References}

1. Torre LA, Bray F, Siegel RL, Ferlay J, Lortet-Tieulent J, Jemal A. Global cancer statistics, 2012. CA Cancer J Clin. 2015;65:87-108.

2. Siegel R, Ma J, Zou Z, Jemal A. Cancer statistics, 2014. CA Cancer J Clin. 2014;64:9-29.

3. Muller A, Homey B, Soto H, et al. Involvement of chemokine receptors in breast cancer metastasis. Nature. 2001;410:50-56.

4. Choi YJ, Kim ST, Park KH, et al. The serum bone morphogenetic protein-2 level in non-small-cell lung cancer patients. Med Oncol. 2012; 29:582-588.

5. Domanska UM, Kruizinga RC, Nagengast WB, et al. A review on CXCR4/CXCL12 axis in oncology: no place to hide. Eur J Cancer. 2013;49:219-230.

6. Hall JM, Korach KS. Stromal cell-derived factor 1, a novel target of estrogen receptor action, mediates the mitogenic effects of estradiol in ovarian and breast cancer cells. Mol Endocrinol. 2003;17:792-803.

7. TaichmanRS,CooperC,KellerET,PientaKJ,TaichmanNS, McCauleyLK. Use of the stromal cell-derived factor-1/CXCR4 pathway in prostate cancer metastasis to bone. Cancer Res. 2002;62:1832-1837.

8. Kaifi JT, Yekebas EF, Schurr P, et al. Tumor-cell homing to lymph nodes and bone marrow and CXCR4 expression in esophageal cancer. J Natl Cancer Inst. 2005;97:1840-1847.

9. Kim SY, Lee CH, Midura BV, et al. Inhibition of the CXCR4/CXCL12 chemokine pathway reduces the development of murine pulmonary metastases. Clin Exp Metastasis. 2008;25:201-211.

10. Zagzag D, Krishnamachary B, Yee H, et al. Stromal cell-derived factor-1alpha and CXCR4 expression in hemangioblastoma and clear cell-renal cell carcinoma: von Hippel-Lindau loss-of-function induces expression of a ligand and its receptor. Cancer Res. 2005; 65:6178-6188.

11. Orimo A, Gupta PB, Sgroi DC, et al. Stromal fibroblasts present in invasive human breast carcinomas promote tumor growth and angiogenesis through elevated SDF-1/CXCL12 secretion. Cell. 2005;121: 335-348.

12. Liang Z, Brooks J, Willard M, et al. CXCR4/CXCL12 axis promotes VEGF-mediated tumor angiogenesis through Akt signaling pathway. Biochem Biophys Res Commun. 2007;359:716-722.

13. De Falco V, Guarino V, Avilla E, et al. Biological role and potential therapeutic targeting of the chemokine receptor CXCR4 in undifferentiated thyroid cancer. Cancer Res. 2007;67:11821-11829.

14. Wang Z, Ma Q, Liu Q, et al. Blockade of SDF-1/CXCR4 signalling inhibits pancreatic cancer progression in vitro via inactivation of canonical Wnt pathway. Br J Cancer. 2008;99:1695-1703.

15. Bartolome RA, Ferreiro S, Miquilena-Colina ME, et al. The chemokine receptor CXCR4 and the metalloproteinase MT1-MMP are mutually required during melanoma metastasis to lungs. The Am J Pathol. 2009; $174: 602-612$

16. Scala S, Ottaiano A, Ascierto PA, et al. Expression of CXCR4 predicts poor prognosis in patients with malignant melanoma. Clin Cancer Res. $2005 ; 11: 1835-1841$
17. Yopp AC, Shia J, Butte JM, et al. CXCR4 expression predicts patient outcome and recurrence patterns after hepatic resection for colorectal liver metastases. Ann Surg Oncol. 2012;19(Suppl 3):S339-S346.

18. Akashi T, Koizumi K, Tsuneyama K, Saiki I, Takano Y, Fuse H. Chemokine receptor CXCR4 expression and prognosis in patients with metastatic prostate cancer. Cancer Sci. 2008;99:539-542.

19. Caruz A, Samsom M, Alonso JM, et al. Genomic organization and promoter characterization of human CXCR4 gene. FEBS Lett. 1998;426: 271-278.

20. Bleul CC, Farzan M, Choe H, et al. The lymphocyte chemoattractant SDF-1 is a ligand for LESTR/fusin and blocks HIV-1 entry. Nature. 1996;382:829-833.

21. Oberlin E, Amara A, Bachelerie F, et al. The CXC chemokine SDF-1 is the ligand for LESTR/fusin and prevents infection by T-cell-lineadapted HIV-1. Nature. 1996;382:833-835.

22. Zeelenberg IS, Ruuls-Van Stalle L, Roos E. The chemokine receptor CXCR4 is required for outgrowth of colon carcinoma micrometastases. Cancer Res. 2003;63:3833-3839.

23. Burger M, Glodek A, Hartmann T, et al. Functional expression of CXCR4 (CD184) on small-cell lung cancer cells mediates migration, integrin activation, and adhesion to stromal cells. Oncogene. 2003;22: 8093-8101.

24. Staller P, Sulitkova J, Lisztwan J, Moch H, Oakeley EJ, Krek W. Chemokine receptor CXCR4 downregulated by von Hippel-Lindau tumour suppressor pVHL. Nature. 2003;425:307-311.

25. Robledo MM, Bartolome RA, Longo N, et al. Expression of functional chemokine receptors CXCR3 and CXCR4 on human melanoma cells. J Biol Chem. 2001;276:45098-45105.

26. Payne AS, Cornelius LA. The role of chemokines in melanoma tumor growth and metastasis. $J$ Invest Dermatol. 2002;118:915-922.

27. Kim J, Takeuchi H, Lam ST, et al. Chemokine receptor CXCR4 expression in colorectal cancer patients increases the risk for recurrence and for poor survival. $J$ Clin Oncol. 2005;23:2744-2753.

28. Matsusaka S, Mishima Y, Suenaga M, et al. Circulating endothelial progenitors and CXCR4-positive circulating endothelial cells are predictive markers for bevacizumab. Cancer. 2011;117:4026-4032.

29. Tamamura H, Fujisawa M, Hiramatsu K, et al. Identification of a CXCR4 antagonist, a T140 analog, as an anti-rheumatoid arthritis agent. FEBS Lett. 2004;569:99-104.

30. Takenaga M, Tamamura H, Hiramatsu K, et al. A single treatment with microcapsules containing a CXCR4 antagonist suppresses pulmonary metastasis of murine melanoma. Biochem Biophys Res Commun. 2004; 320:226-232.

31. Lin F, Zheng SE, Shen Z, et al. Relationships between levels of CXCR4 and VEGF and blood-borne metastasis and survival in patients with osteosarcoma. Med Oncol. 2011;28:649-653.
OncoTargets and Therapy

\section{Publish your work in this journal}

OncoTargets and Therapy is an international, peer-reviewed, open access journal focusing on the pathological basis of all cancers, potential targets for therapy and treatment protocols employed to improve the management of cancer patients. The journal also focuses on the impact of management programs and new therapeutic agents and protocols on
Dovepress

patient perspectives such as quality of life, adherence and satisfaction The manuscript management system is completely online and includes a very quick and fair peer-review system, which is all easy to use. Visit http://www.dovepress.com/testimonials.php to read real quotes from published authors. 